\title{
Normal skin of HIV-infected individuals contains increased numbers of dermal CD8 $T$ cells and normal numbers of Langerhans cells
}

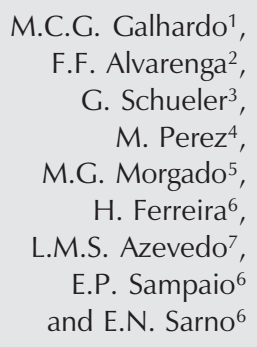

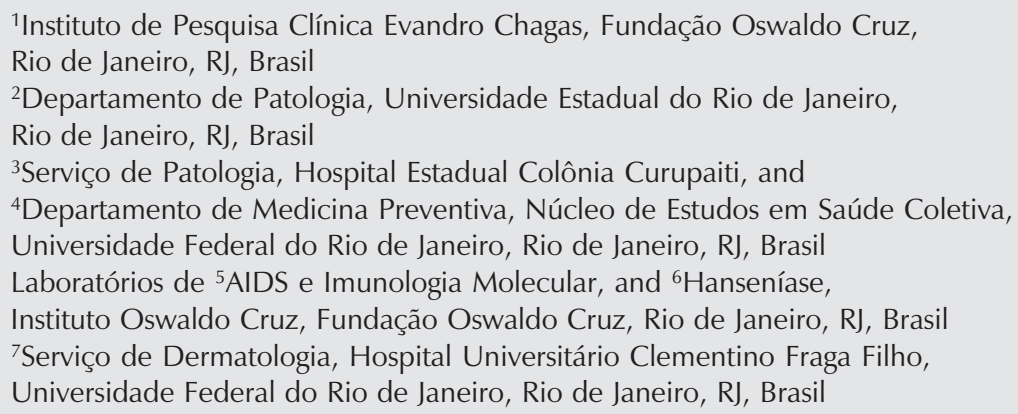

\section{Correspondence}

M.C.G. Galhardo

Instituto de Pesquisa Clínica

Evandro Chagas, FIOCRUZ

Avenida Brasil, 4365

22045-900 Rio de Janeiro, RJ

Brasil

Fax: +55-21-2590-9988

E-mail: mclara@ipec.fiocruz.br

$\ldots \ldots \ldots \ldots \ldots \ldots \ldots$

Received May 27, 2003 Accepted December 2, 2003

\section{Abstract}

Dysregulation of the skin immune system (SIS) could explain the high prevalence of skin disorders in HIV+ individuals. The present study was carried out to determine whether alterations in the cell population of SIS and epidermal immunoactivation occur in the normal skin of HIV+ individuals. Forty-five biopsies were taken from the normal upper arm skin of $45 \mathrm{HIV}+$ patients and of 15 healthy controls. HIV+ individuals were divided into three categories according to their CD4 cell blood count $(<200,200-499$ and $\geq 500 / \mu 1)$. Hematoxylin-eosin was used to stain tissue sections for morphological analysis and immunohistochemistry was used for the evaluation of the frequency of macrophages, Langerhans cells, and CD lymphocyte subsets. In addition, semiquantitative analysis of LFA-1, ICAM-1 and HLA-DR was determined in epidermal cells. Macrophages, Langerhans cells, and CD lymphocyte subsets did not differ significantly between any of the patient categories and the control group. When all HIV+ individuals were compared as a group to the control group, a significant increase in dermal CD8+ $\mathrm{T}$ lymphocytes $(\mathrm{P}<0.01)$ and lower $\mathrm{CD} 4-\mathrm{CD} 8$ ratios $(\mathrm{P}<0.01)$ were observed in the HIV+ individuals. Epidermal ICAM1 and HLA-DR expression was negative in both HIV+ and normal skin biopsies. No evidence of a depletion of the SIS population or of epidermal immunoactivation in normal skin from HIV+ individuals was demonstrable, suggesting that alterations in the central immune system are not necessarily reflected in the SIS of HIV-infected patients.
Key words

- HIV

- Skin immune system

- CD8 T cells

- CD4-CD8 ratio

- Langerhans cells 


\section{Introduction}

During HIV infection, the skin is an organ of major morbidity. Increasingly severe cutaneous disorders most commonly occur during the course of the disease and sometimes they provide the earliest clue to the existence of HIV or of its progression (1-3). Suggestive of both local permissiveness and responsiveness to the presence of HIV, a change in the cutaneous environment also appears to take place. As such, an dysregulation of the skin immune system (SIS) could be the prime reason for the increasing prevalence of skin disorders in HIV+ individuals (4-7). However, few studies have been conducted on the SIS of HIV+ patients, in whom, similar to what occurs in other specialized lymphoid systems, changes in the immune cells associated with the SIS would be predictable (8-10).

Most of the studies on SIS in HIV infection have focused on the role of Langerhans cells (Lc), most probably because of their important function as antigen-presenting cells and because of their expression of CD4 cells. Although results continue to be contradictory, the hypothesis that the Lc population may suffer alterations during infection has been the subject of numerous studies (1116). Few data are available regarding the role of $\mathrm{T}$ cells and the other components. Skin mast cell density has been shown to remain unchanged in HIV+ individuals (17). Even though keratinocytes do not become infected with HIV, they are capable of secreting a variety of immunomodulatory cytokines (interleukin (IL)-1, IL-6 and tumor necrosis factor- $\alpha$ ) which may enhance HIV replication and the spreading of the virus in the skin $(7,18)$. In addition, as can be seen in a wide variety of dermatoses, keratinocytes may become immunoactivated by means of the induction of expression molecules, such as the intercellular adhesion molecule 1 (ICAM-1) and human leukocyte antigen (HLA)-DR, responsible for the increase in lymphocyte traffic in the epidermis and its susceptibility to inflammatory reactions (19).

The skin-related mechanisms in HIV infection are unknown, although SIS dysregulation has been consistently thought to play a role in triggering dermatoses. Using histological and immunohistochemical techniques, we attempted to determine whether the SIS becomes impaired in the clinically normal-appearing skin of $\mathrm{HIV}+$ patients at different stages of infection. The number of skin immune cells (Lc, dermal dendrite cells, $\mathrm{T}$ cell subsets and macrophages), the extent of perivascular infiltrates, and the presence of immunoactivated cell components (HLADR, ICAM-1 and leukocyte function-associated antigen-1 (LFA-1)) were determined in situ.

\section{Material and Methods}

\section{Subjects}

After obtaining written informed consent from patients and control subjects and approval from the Ethics Committee of the Oswaldo Cruz Foundation, $45 \mathrm{HIV}+$ patients (27 males and 18 females; mean age, $37.2 \pm$ 6.6 ; range, 25-50 years) were randomly selected to participate in this cross-sectional study. Patients with systemic or cutaneous diseases that might interfere with the study were excluded from the investigation. HIV patients were further grouped according to their CD4+ cell count as follows: $<200 / \mu 1$ (category I, AIDS patients, $\mathrm{N}=15$ ); 200 to $499 / \mu 1$ (category II, $\mathrm{N}=15$ ); $\geq 500 / \mu 1$ (category III, $\mathrm{N}=15)$. Thirty-one $(68 \%)$ patients were taking antiretroviral agents at the time of the study; 15 were receiving two drugs (mean time, 7.8 months; range, 2 to 14 months); 15 , triple drug therapy (mean time, 6.3 months; range, 1 to 10 months), and 1 , quadruple drug therapy (1 month; nucleoside reverse transcriptase inhibitors, zidovudine, didanosine, dideoxycytidine, and lamivudine in addition to the protease inhibi- 
tors saquinavir and ritonavir) in a variety of combinations (Table 1). The control group consisted of 15 healthy individuals ( 8 males and 7 females; mean age, $35.4 \pm 7.4$; range, 20-42 years).

\section{Skin biopsies}

Punch biopsies $(6 \mathrm{~mm})$ were obtained from clinically normal skin on the sun-protected inner side of the upper arm from HIV patients and control subjects. Biopsy samples were cut into two parts and processed for histological and immunohistochemical evaluation as described below.

\section{Histopathological analysis}

The skin fragment was fixed in $10 \%$ neutral-buffered formalin overnight, embedded in paraffin, and stained with hematoxylineosin. The material was submitted to the following morphological determinations: 1) count of the number of layers in the epidermis and analysis of the keratinocytes in each layer; 2) evaluation of the dermal and subcutaneous adnexa and blood vessels, and 3) measurement of the extension of the inflammatory infiltrate. Samples were examined by two independent observers and morphological features were recorded. Quantitative measurements (mean \%) of the infiltrated area were made during microscopic examination (100X magnification) of histological sections using a ProLite image analyzer, which permitted the viewing of fields with a Nikon E 450 microscope. For each sample, three different fields of the upper dermis were scanned (20X). The most extended infiltrates (four of them) were identified and measured in each field (40X), and the mean of each sample was calculated.

\section{Immunohistochemistry}

Biopsies were snap-frozen and kept in liquid nitrogen until the time for use. Frozen sections were cut with a cryostat, air dried, and fixed in cold acetone for $10 \mathrm{~min}$. The sections were incubated with the primary antibody for $60 \mathrm{~min}$, washed in PBS, and then incubated with the biotinylated secondary antibody (Dako Corporation, Carpinteria, CA, USA), followed by the avidin-biotin-peroxidase complex (Vectastain $\mathrm{ABC}$ kit; Vector Laboratories, Inc., Burlingame, CA, USA), and processed according to manufacturer instructions. Finally, sections were developed with aminoethylcarbazole as the chromogenic substrate. In control specimens, the primary monoclonal antibody was omitted or isotype control antibodies of irrelevant specificity were used. The sections were analyzed by light microscopy and photomicrographs were taken with a Nikon Microphot system.

\section{Antibodies}

Mouse anti-human monoclonal antibodies were used for the identification of specific cell types, proteins, and surface molecules. AntiCD1 (Lc) antibody, anti-CD3 (pan T cell marker), anti-CD4, anti-CD8 $\mathrm{T}$ cell subsets,

Table 1. Clinical data of the HIV+ individuals enrolled in the present study.

\begin{tabular}{lccc}
\hline & Category I & Category II & Category III \\
\hline $\begin{array}{l}\text { Median age in years } \\
\text { (range in years) }\end{array}$ & 39.1 & 38.2 & 34.2 \\
Gender & $(32.7-47)$ & $(30-50)$ & $(25-42)$ \\
$\quad$ Male (\%) & $10(22)$ & $9(20)$ & $8(18)$ \\
Female (\%) & $5(11)$ & $6(13.1)$ & $7(15.5)$ \\
Exposure group & & & \\
Homo/bisexual (\%) & $5(11.1)$ & $3(6.6)$ & $3(6.6)$ \\
Heterosexual (\%) & $7(15.5)$ & $12(26.6)$ & $9(20)$ \\
Blood products (\%) & - & - & $1(2.2)$ \\
Unknown (\%) & $3(6.6)$ & - & $2(4.4)$ \\
Concomitant diseases (\%) & & & - \\
$\quad$ Tuberculosis & $3(6.6)$ & - & - \\
Atypical mycobacteriosis infection & $2(4.4)$ & - & - \\
Kaposi's sarcoma & $1(2.2)$ & - & - \\
\hline
\end{tabular}

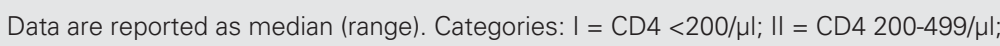
III = CD4 $2500 / \mu \mathrm{l}$. 
anti-CD45RO (previous activated T cells), and anti-CD45RA (naive $\mathrm{T}$ cells) were obtained from Becton \& Dickinson (San Jose, CA, USA) and were diluted 1:25 in PBS. AntiCD68 (macrophage marker; Dako Corporation) and anti-HLA-DR (Becton \& Dickinson) were diluted 1:100. Anti-ICAM-1 and antiLFA-1 were obtained from Immunotech
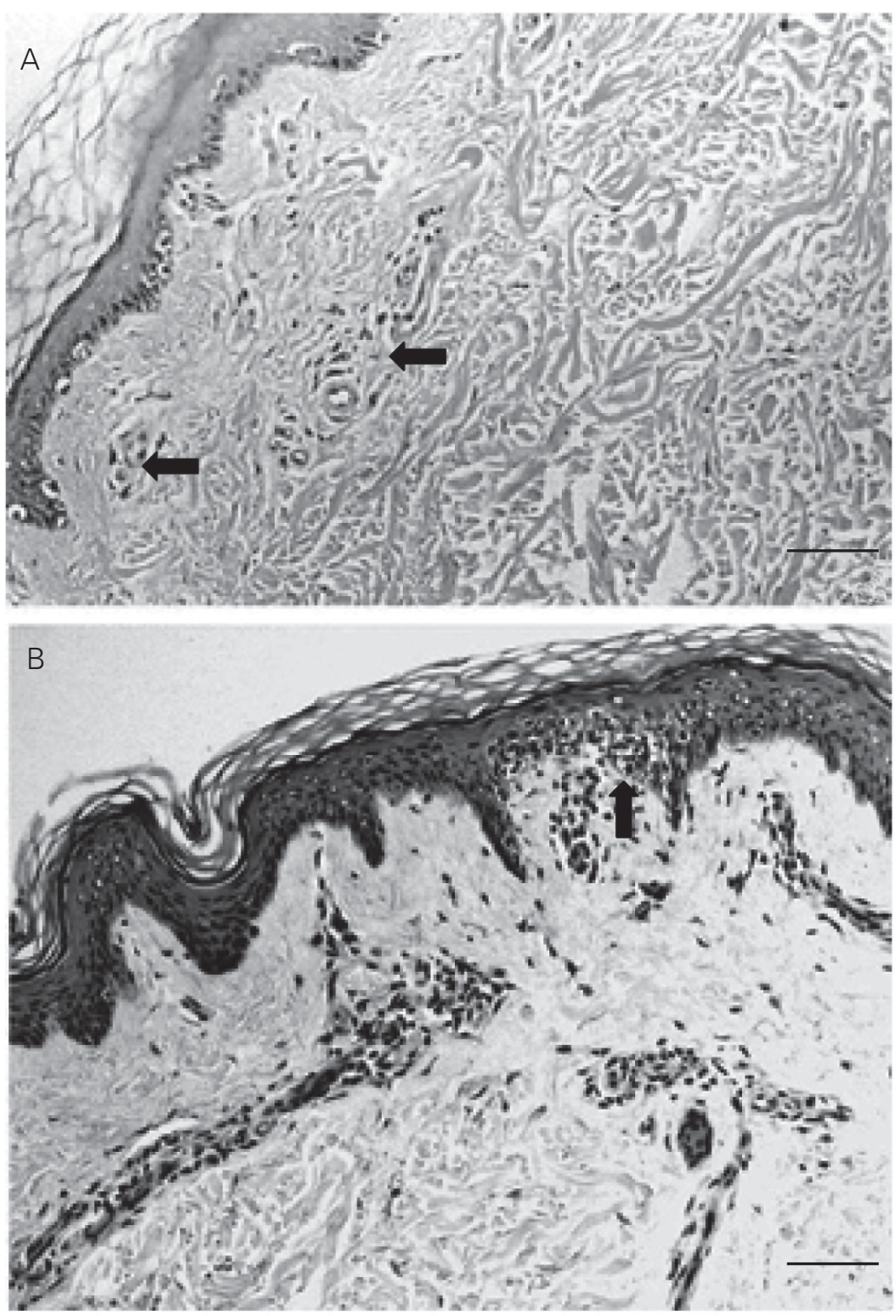

Figure 1. Normal skin biopsies obtained from HIV+ patients. Two different patterns of superficial dermal cellular infiltrate are shown. $A$, There are rare cells in the inflammatory infiltrate (arrows). Hematoxylin-eosin staining, 200X. B, The dermal cellular infiltrate is mostly perivascular and consists largely of lymphocytes with discrete extension into the dermis (arrow). Hematoxylin-eosin staining, Original magnification, 200X. Bars $=80 \mu \mathrm{m}$.
(Marseille, France) and were used at 1:50 dilution. The antibody concentration used was found to be optimal, providing maximum specific staining with the lowest background signal. Positive cells were identified by reddishbrown staining and compared with the control slides from which the primary antibody had been omitted. Staining for CD1 cells was considered to be positive when the cell body was seen to have one or more dendritic processes. The total number of CD1-positive epidermal cells per field was determined by using a $40 \mathrm{X}$ objective for the length of the epidermis. The result was the ratio between the number of positive cells and the number of fields covering the length of the epidermis. For quantification of CD3, CD4, CD8, CD45RO, CD45RA, and macrophages in the dermal infiltrate, counting was performed by focusing on the largest infiltrates in five fields in which the total number of positive cells per field was counted with 40X and 100X objectives. For HLA-DR, ICAM-1 and LFA-1 expression, semiquantitative analysis was performed as follows: for HLA-DR, $(0)=$ only Lcs were stained, $(+)=$ epidermal cells were stained not including all the layers or the total length of the epidermis, and $(++)=$ all positive epidermal cells were stained. For ICAM-1, $(0)=$ when the epidermis was negative, $(+)=$ only one area stained positive, and $(++)=$ more than one area stained positive. For LFA-1, $(0)=$ absent staining, $(+)=$ sparse staining, $(++)=$ moderate staining, and $(+++)=$ intense staining.

Viral load and $T$ lymphocyte subsets. Blood samples were collected by venipuncture from all participants at the time of biopsy into Vacutainer tubes containing EDTA and heparin for the determination of viral load and $\mathrm{T}$ lymphocyte subsets, respectively.

HIV-1 RNA was determined by quantitative nucleic acid sequence-based amplification (Organon, Teknika, Boxtel, The Netherlands), as recommended by the manufacturer. The detection limit of the assay was $<400$ copies/ml. CD3, CD4 and CD8 lymphocyte counts were determined by four- 
color staining (CD45, CD3, CD4, CD8) using standard flow cytometry.

\section{Statistical analysis}

Results are reported as mean $\pm \mathrm{SD}$. A simple description of variables was elaborated in order to compare the different HIV categories and controls with respect to clinical and laboratory data. ANOVA (Scheffé) and the chi-square test (Fischer) were used to measure the effect of HIV staging associated to independent variables. In addition, the Pearsonproduct-moment correlation coefficient (r) was calculated. The level of significance was set at $\mathrm{P}<0.05$ in all analyses.

\section{Results}

\section{Histological analysis}

Hematoxylin-eosin staining showed a similar histological pattern and a nonspecific dermis infiltrate in HIV patients and control subjects. No major differences in mean percent area occupied by the infiltrate were noted between the patient categories and the control group, with values of $702.8 \pm$ 621.6 for category I, $448.8 \pm 274.8$ for category II, $626.4 \pm 408.6$ for category III, and $749.5 \pm 462.3$ for controls. Similarly, there was no statistically significant difference between HIV + individuals $(592.6 \pm 760.1)$ and controls (749.5 \pm 462.3 ; Figure 1A,B).

\section{Immunohistological evaluation}

Immunohistological staining of frozen biopsies for $\mathrm{T}$ cell subsets showed that the numbers of CD3, CD4 and CD8 T lymphocytes and the CD4-CD8 lymphocyte ratio in the perivascular dermis did not differ significantly among patient categories or between groups of HIV patients and controls (Table 2 and Figure 2B,C). However, a significant increase in $\mathrm{CD} 8 \mathrm{~T}$ lymphocytes was detected in HIV+ individuals $(5.3 \pm 7.3)$ in the
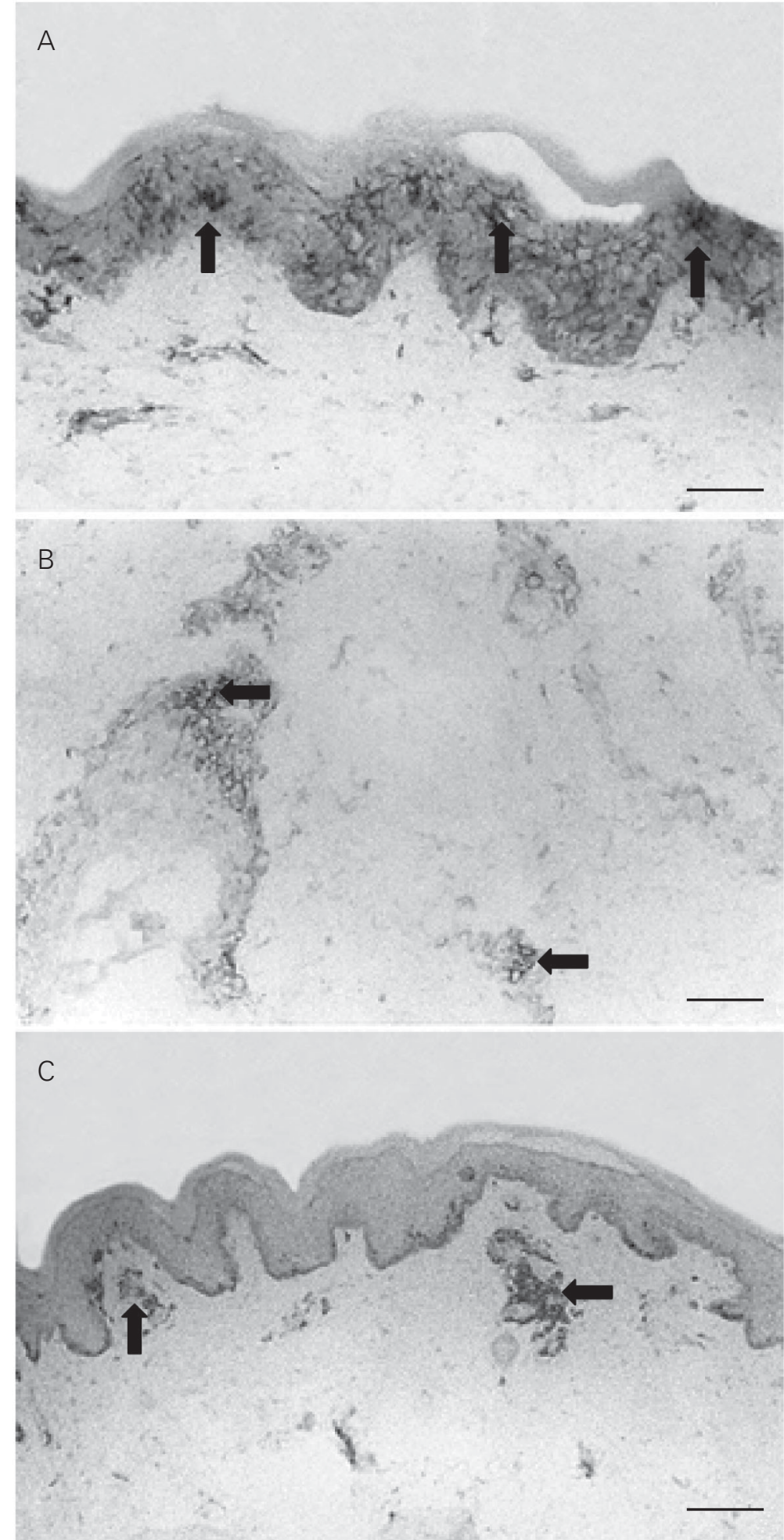

Figure 2. Normal skin biopsies obtained from HIV+ patients. A, There is a diffuse distribution of Langerhans cells (arrows) in the epidermis. Few Langerhans cells are present in the dermis (anti-CD1 staining, 200X). B, CD4 T lymphocytes (arrows) are present in the dermal cellular infiltrate (anti-CD8 staining, 200X). C, CD8 T lymphocytes (arrows) are shown in the dermal cellular infiltrate (anti-CD4 T staining, Original magnification, 200X. Bars $=80 \mu \mathrm{m}$. 
perivascular dermis compared to control $(0.6$ $\pm 1 ; \mathrm{P}<0.01)$. In addition, these patients presented a lower CD4-CD8 ratio $(2 \pm 3.4)$ compared to control $(5.1 \pm 5.6 ; \mathrm{P}<0.01)$. A positive correlation was also observed between the number of CD3 and CD8 T lymphocytes $(r=0.29 ; \mathrm{P}<0.028)$ and between the number of CD4 lymphocytes and the CD4-CD8 ratio in the perivascular dermis ( $\mathrm{r}$ $=0.80 ; \mathrm{P}<0.001)$ in all individuals. Staining for the CD45RO and CD45RA isoforms showed no differences among the various groups (data not shown).

\section{Langerhans cells}

The mean Lc density in the epidermis was not significantly different between the patient categories and the control group or between HIV+ individuals as a whole and controls. Lc density was $30.1 \pm 32.3$ in category I, $19 \pm 16.9$ in category II, $19.6 \pm 17.4$ in category III, and $21 \pm 14.8$ in the control group. Mean dermal dendritic cell density was as follows: $3.8 \pm 1.6$ in category I, $1.3 \pm$ 1.6 in category II, $3.3 \pm 4.8$ in category III, and $1.5 \pm 1.7$ in the control group. Among HIV+ individuals, mean Lc density and dermal dendritic cell density were $25.1 \pm 23.3$ and $3.2 \pm 5.7$, respectively, as compared to
$22.5 \pm 14.4$ and $1.0 \pm 1.4$ for the control group (Figure 2A). Likewise, the mean macrophage cell density in the dermis was not significantly different between the HIV+ categories and the control group or among the different patient categories (data not shown). Epidermal HLA-DR and ICAM-1 expression was negative in the keratinocytes $(0+)$ and LFA-1 and ICAM-1 were expressed constitutively in the blood vessels and in dermal lymphocytes.

\section{Correlation between CD8 T lymphocytes in the perivascular dermis infiltrate and $T$ lymphocyte subsets in the blood}

The number of CD3-, CD4- and CD8positive cells in blood was estimated in all the individuals enrolled in the study. As expected, CD4 cell averages were significantly different between the various categories (except category III, CD4 $\geq 500 / \mu \mathrm{l}$ ) and the control group, and individuals with AIDS presented the lowest averages (Table 2). When data for all HIV+ individuals were pooled, lower mean CD4-CD8 ratios were detected $(0.44 \pm 0.45)$ compared to the control group $(2.12 \pm 1.24 ; \mathrm{P}<0.001)$. Moreover, evaluation of the cellular infiltrate showed a positive correlation between CD8

Table 2. Numbers of CD4 and CD8 T cells in the perivascular dermis and blood.

\begin{tabular}{lcccc}
\hline & Category I & Category II & Category III & Control group \\
\hline Perivascular dermis & & & & \\
CD4 cells & $6.6 \pm 10.2$ & $4.1 \pm 4.9$ & $7.06 \pm 6.4$ & $5.8 \pm 6$ \\
CD8 cells & $5.5 \pm 9.6$ & $4.5 \pm 6.5$ & $6 \pm 6.1$ & $0.6 \pm 1$ \\
CD4-CD8 ratio & $1.808 \pm 2.8$ & $2.9 \pm 5.1$ & $1.35 \pm 1.1$ & $5.1 \pm 5.5$ \\
Blood & & & & \\
CD4 cells & $96.7 \pm 58.4^{\mathrm{a}}$ & $344.0 \pm 76.6^{\mathrm{b}}$ & $756.0 \pm 38.8$ & $809.9 \pm 201.8$ \\
CD8 cells & $1247.8 \pm 2506.8$ & $1230.6 \pm 818.9$ & $3243.5 \pm 4785.5$ & $466.3 \pm 144.5$ \\
CD4-CD8 ratio & $0.2 \pm 0.1^{\mathrm{c}}$ & $0.4 \pm 0.2^{\mathrm{d}}$ & $0.8 \pm 0.6$ & $2.1 \pm 1.2$ \\
\hline
\end{tabular}

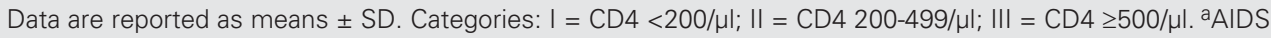
patients had significantly lower numbers of CD4 lymphocytes in blood compared with category II $(P<0.02)$, category III (P< 0.001), and control $(P<0.001)$. bIn category II, CD4 numbers were also significantly lower compared to category III $(P<0.001)$, and to control $(P<0.001)$. ${ }^{\text {CThe }}$ CD4-CD8 T lymphocyte ratio was significantly lower for the AIDS group compared to control $(P<0.001)$, and for dcategory II compared to control $(P<0.001)$. ANOVA was used for all comparisons. 
perivascular T lymphocyte counts and CD8 counts in blood $(\mathrm{r}=0.29 ; \mathrm{P}<0.02)$ and $\mathrm{a}$ negative correlation between perivascular CD8 T cells and the CD4-CD8 ratio in blood $(\mathrm{r}=0.31 ; \mathrm{P}<0.01)$

With respect to viral load, 37 patients showed detectable levels of HIV-1 RNA in plasma with no significant difference among the 3 groups (category I: $4.72 \pm 0.69$, category II: $3.9 \pm 0.85$, and category III: $4.4 \pm$ $0.85)$. No correlations were detected between cell components and viral load.

\section{Discussion}

In view of the great importance of skin morbidity in HIV infection and the scarcity of studies on the possible participation of the SIS in the development of the disease, the original purpose of this study was to ascertain the morphological aspects and to characterize the cell population of the immune system in the normal skin of HIV+ individuals.

Most of the patients in this study were receiving antiretroviral therapy, a fact that might probably have had some impact on the results. Generally, the introduction of highly active antiretroviral therapy is associated with significantly lower cutaneous morbidity in HIV patients (20-23). However, despite the antiretroviral therapy, it was possible to divide the population studied into categories according to the variations observed in their CD4 T cell counts, which indicated sharply different degrees of immunodeficiency $(\mathrm{P}<$ 0.05 ), especially considering individuals with AIDS (category I), who were severely immunodepressed (CD4 = 96/ $\mu 1)$.

In the present study, surprisingly, no reduction in CD4 counts was found in the perivascular infiltrate of the dermis, nor did we observe any propensity toward the loss of CD45RO cells, normally described to occur in the earlier stages of HIV infection (24). This finding appears to indicate that the CD4 cells are preserved in the skin in contrast to the decreased number in peripheral blood. In addition, the dynamic process of replication/ destruction of CD4+ $\mathrm{T}$ cells seems to be occurring in most patients, as indicated by the presence of HIV-1 RNA in plasma.

In contrast, among HIV+ individuals, an increase of $\mathrm{CD} 8 \mathrm{~T}$ cells was noted in the perivascular dermis. Cases of skin $\mathrm{CD} 8+\mathrm{T}$ cell infiltrate associated with advanced HIV infection have been described (25-30). Functional studies with CD8 $\mathrm{T}$ cells obtained from the HIV skin infiltrates have shown a cytotoxic immune response to HIV protein. It has been suggested that, in addition to their known role in controlling the retroviral infection, these cytotoxic $\mathrm{T}$ lymphocytes may also be involved in the pathogenesis of the cutaneous inflammatory disorders occurring during the course of the disease $(26,27)$. In this respect, a cutaneous lymphoma expressing a CD8 $\mathrm{T}$ cell phenotype has been reported in HIV patients (31).

Furthermore, the reversed CD4-CD8 T cell ratio reported for blood (described in the present study), as well as in other specialized lymphoid systems and clearly observed during HIV infection, was not seen in the dermis (Table 2) $(9,10,32)$. Nevertheless, the perivascular CD4-CD8 ratio was significantly lower in HIV-infected patients compared to the control group, a fact that could probably be attributed to the increased number of $\mathrm{CD} 8+$ $\mathrm{T}$ cells.

As reported in other recent studies involving a larger number of patients, there was no detectable reduction in Lc density in the normal-appearing skin(14-16). Although Lc is the sole cell of the epidermis that can be infected by HIV $(33,34)$, simultaneously allowing the efficient replication of the virus $(35,36)$, the frequency of infected Lc is low (37). It would appear then that the involvement of Lc in HIV infection is a great deal more qualitative than quantitative in nature $(38,39)$.

Similarly, no alterations in the number of macrophages was observed either in the HIV+ 
patients or between them and the control group. Previous studies have also failed to detect any HIV viral particles or viruses in such cells (40). On the other hand, in other sites such as the lung, where HIV can be isolated from $50 \%$ of the macrophages in bronchoalveolar lavage fluids, numerical, phenotypical, and functional changes in macrophages have been reported to occur (3). Similarly, no increase in HLA-DR or ICAM1 expression was observed in keratinocytes, suggesting that there is no inflammatory response in the normal skin of HIV+ individuals.

The present study has shown the preservation of immune cells such as dermal CD4+ $\mathrm{T}$ cells, dermal dendritic cells, macrophages, and Lc in the normal skin of HIV patients. It can now be convincingly argued that the skin is not a major site of HIV replication and that the SIS in HIV infection acts differently from other local immune systems where HIVrelated changes take place. Conversely, it would seem that subtle interactions do occur, as indicated mainly by the increased number of CD8+ $\mathrm{T}$ cells in the skin. Although in the present study we did not assess the activation of CD8 cells, the presence of an increased number of cells in the perivascular normal skin may somehow lead to tissue damage, and, thereby actually contributing to the pathogenesis of skin disease in HIV infection.

\section{Acknowledgments}

The authors wish to thank Dr. Sérgio Luiz Gomes Antunes for helpful advice and the Laboratório de Produção e Tratamento de Imagens, Instituto Oswaldo Cruz, Rio de Janeiro, RJ, Brazil, for the figures.

\section{References}

1. Coldiron BM \& Bergstresser PR (1989). Prevalence and clinical spectrum of skin disease in patient infected with human immunodeficiency virus. Archives of Dermatology, 125: 357-361.

2. Uthayakumar $S$, Nanwani R, Drinkwater T, Nayagam AT \& Darley CR (1997). The prevalence of skin disease in HIV infection and its relationship to the degree of immunosuppression. British Medical Journal, 137: 595-598.

3. Spira R, Mignard M, Doutre MS, Morlat P \& Dabis F (1998). Prevalence of cutaneous disorders in a population of HIV-infected patients. Archives of Dermatology, 34: 1208-1212.

4. Duvic M (1995). Human immunodeficiency virus and the skin: selected controversies. Journal of Investigative Dermatology, 105 (Suppl): 117S-121S.

5. Tschachler E, Bergstresser PR \& Stingl G (1996). HIV-related skin diseases. Lancet, 348: 659-663.

6. Henry M \& Tschachler E (1996). The skin immune system in the course of HIV-1 infection. Photochemistry and Photobiology, 64: 275-279.

7. Blauvelt A \& Katz SI (1995). The skin as target, vector, and effector organ in human immunodeficiency virus disease. Journal of Investigative Dermatology, 105: 122S-126S.

8. Bray DH, Squire SB, Bagdades E, Mulvenna PM, Johnson MA \& Poulter LW (1992). Alveolar macrophage populations are distorted in immunocompromised patients with pneumonitis. European Respiratory Journal, 5: 545-552.

9. Lim SG, Condez A, Lee CA, Johnson MA, Elias C \& Poulter L (1993). Loss of mucosal CD4 lymphocytes is an early feature of HIV infection. Clinical and Experimental Immunology, 92: 448-454.
10. Olaitan A, Johnson MA, MacLean A \& Poulter LW (1996). The distribution of immunocompetent cells in the genital tract of HIVpositive women. AIDS, 10: 759-764.

11. Belsito DV, Sanchez MR, Baer RL, Valentine F \& Thorbecke J (1984). Reduced Langerhans' cell la antigen and ATPase activity in patients with the acquired immunodeficiency syndrome. New England Journal of Medicine, 310: 1279-1282.

12. Dréno B, Milpied B, Bignon JD, Stalder JF \& Litoux $P$ (1988). Prognostic value of Langerhans cells in the epidermis of HIV patients. British Journal of Dermatology, 118: 481-486.

13. Kanitakis J, Marchand C, Su H, Thivolet J, Zambruno G, Schmitt D \& Gazzolo L (1989). Immunohistochemical study of normal skin of HIV-1 infected patients shows no evidence of infection of epidermal Langerhans cells by HIV. AIDS Research and Human Retroviruses, 5: 293-302.

14. Kalter DC, Greenhouse JJ, Orenstein JM, Schnittman SM, Gendelman HE \& Meltzer MS (1991). Epidermal Langerhans cells are not principal reservoirs of virus in HIV disease. Journal of Immunology, 146: 3396-3404

15. Nandwani R, Gazzard BG, Barton SE, Hawkins DA, Zemelman V \& Staughton RC (1996). Does HIV disease progression influence epidermal Langerhans cell density? British Journal of Dermatology, 134: 1087-1092.

16. Comptom CC, Kupper TS \& Nadire KB (1996). HIV-1 infected Langerhans cells constitute a significant proportion of the epidermal Langerhans cell population throughout the course of HIV disease. Journal of Investigative Dermatology, 107: 822-826.

17. Galhardo MC, Perez M, Morgado MG, Almeida S, Azevedo LMS, 
Geog I, Ferreira H \& Sarno EN (2000). Search for evidence of a Th2 profile in HIV+ patients. International Journal of Dermatology, 39: 109-115

18. Oxholm A, Oxholm P \& Permin H (1989). Epidermal tumour necrosis factor $\alpha$ and interleukin 6-like activities in AIDS-related Kaposi's sarcoma. Acta Pathologica et Microbiologica Scandinavica, 97: 533538.

19. Wantzing GL, Ralfkiaer E, Lisby S \& Rothlein R (1989). The role of intercellular adhesion molecules in inflammatory skin reactions. British Journal of Dermatology, 119: 141-145.

20. Mirmirani P, Maurer TA, Berger TG, Sands LP \& Chren MM (2002). Skin-related quality of life in HIV-infected patients on highly active antiretroviral therapy. Journal of Cutaneous Medicine and Surgery, 6: 10-18.

21. Johnson RA (1999). Human immunodeficiency virus disease in the era of HAART: a reevaluation of the mucocutaneous manifestations. Current Clinical Topics in Infectious Diseases, 19: 252-286.

22. Costner M \& Cockerell CJ (1998). The changing spectrum of cutaneous manifestations of HIV infection. Archives of Dermatology, 134: 1290-1292

23. Calista D, Morri M, Stagno A \& Boschini A (2002). Changing morbidity of cutaneous diseases in patients with HIV after the introduction of antiretroviral therapy including a protease inhibitor. American Journal of Clinical Dermatology, 3: 359-362.

24. Gruters RA, Terpstra FG, De Goede RE, Mulder JW, De Wolf F, Schellekens PT, Van Lier RA, Tersmette M \& Miedema F (1991). Immunological and virological markers in individuals progressing from seroconversion to AIDS. AIDS, 5: 837-844.

25. Janier M, Katlama C, Flageul B, Valensi F, Moulonguet I, Sigaux F, Dompmartin D \& Civatte J (1989). The pseudo-Sezary-syndrome with CD8 phenotype in a patient with the acquired immunodeficiency syndrome (AIDS). Annals of Internal Medicine, 110: 738-740.

26. Bachelez H, Hadida F \& Gorochov G (1996). Massive infiltration of the skin by human immunodeficiency virus-specific cytotoxic CD8 T cells (Letter). New England Journal of Medicine, 335: 61-62.

27. Bachelez H, Hadida F, Parizot C, Flageul B, Kemula M, Dubertret L, Debree P \& Gorochov G (1998). Oligoclonal expansion of immunodeficiency virus-specific cytotoxic CD8 T cells in the skin of human immunodeficiency virus-1 infected patients with pseudolymphoma. Journal of Clinical Investigation, 101: 2506-2516.

28. Friedler S, Parisi MT, Waldo E, Wieczorek R, Sidhu G \& Rico MJ (1999). Atypical cutaneous lymphoproliferative disorder in patients with HIV infection. International Journal of Dermatology, 38: 111118.

29. Guitart J, Variakojis D, Kuzel T \& Rosen S (1999). Cutaneous CD8+ T cell infiltrates in advanced HIV infection. Journal of the American
Academy of Dermatology, 41: 722-727.

30. Pirovano S, Signorini L, Facchetti F, Santoro A, Albertin A \& Imberti $L$ (2001). Polyclonal T-cell expansion in a HIV+ patient with atypical cutaneous lymphoproliferative disorder, large granular lymphocyte proliferation and SENV infection. Haematologica, 86: 881-882.

31. Burns MK \& Cooper KD (1993). Cutaneous T-cell lymphoma associated with HIV infection. Journal of the American Academy of Dermatology, 29: 394-399.

32. Bofill M, Janossy G, Lee CA, MacDonald-Burns D, Phillips AN, Sabin C, Timms A, Johnson MA \& Kernof PBA (1992). Laboratory control values for CD4 and CD8 T lymphocytes. Implications for HIV-1 diagnosis. Clinical and Experimental Immunology, 88: 243252.

33. Tschachler E, Groh V, Popovic M, Mann DL, Konrad K, Safai B, Eron L, Veronese FM, Wolff K \& Sting G (1987). Epidermal Langerhans cells - a target for HTLV-III/LAV infection. Journal of Investigative Dermatology, 88: 233-237.

34. Giannetti A, Zambruno G, Cimarelli A, Marconi A, Negroni M Girolomoni G \& Bertazzoni U (1993). Direct detection of HIV-1 in epidermis Langerhans cells of HIV-1 infected patients. Journal of Acquired Immune Deficiency Syndromes, 6: 329-333.

35. Kawamura T, Cohen SS, Borris DL, Aquilino EA, Glushakova S, Margolis LB, Orenstein JM, Offord RE, Neurath AR \& Blauvelt A (2000). Candidate microbicides block HIV-1 infection of human immature Langerhans cells within epithelial tissue explants. Journal of Experimental Medicine, 192: 1491-1500.

36. Reece JC, Handley AJ, Anstee EJ, Morrison WA, Crowe SM \& Cameron PU (1998). HIV-1 selection by epidermal dendritic cells during transmission across human skin. Journal of Experimental Medicine, 187: 1623-1631.

37. Cimarelli A, Zambruno G, Marconi A, Giralomoni G, Bertazzoni U \& Giannetti A (1994). Quantitation by competitive PCR of HIV-1 proviral DNA in epidermal Langerhans cells of HIV-1 infected patients. Journal of Acquired Immune Deficiency Syndromes, 7: 230-235.

38. Blauvelt A, Clerici M, Lucey DR, Steinberg SM, Yarchoan R, Walker R, Shearer GM \& Katz SI (1995). Functional studies of epidermal Langerhans cells and blood monocytes in HIV-1 infected persons. Journal of Immunology, 154: 3506-3515.

39. Blauvelt A, Chougnet C, Shearer GM \& Katz SI (1996). Modulation of $T$ cell responses to recall antigens presented by Langerhans cells in HIV-discordant identical twins by anti-interleukin (IL)-10 antibodies and IL-12. Journal of Clinical Investigation, 97: 1550-1555.

40. Kalter DC, Gendelman HE \& Meltzer MS (1991). Monocytes, dendritic cells, and Langerhans cells in human immunodeficiency virus infection. Dermatologic Clinics, 9: 415-428. 